米井 彰洋, 森山 裕一

要旨

抗血小板薬 2 剂併用療法後, アスピリン単剂継続下で手術を行った経皮的冠動脈形成術後の肺癌肺切除症例を報告する. 症例は 70 歳男性. 当院紹介 2 週間前に労作性狭心症にて前医へ入院となり, 薬剂溶出性ステントが留置された. 直後より アスピリン，およびクロピドグレルが開始となった，同入院中に，左肺腫瘍が指摘されたため，当科へ紹介となった。

抗血小板薬 2 剂併用療法が終了する 3 力月を待った後, 冠動脈造影にてステント留置部の良好な開存を確認し, アスピリ ン単剤とした，経過中，左下葉肺腫瘍性病変は $23 \mathrm{~mm}$ から $46 \mathrm{~mm}$ へリイズアップを認め，超音波ガイド下経皮針生検で 扁平上皮癌の診断を得た。造影 CT, PET CT でリンパ節転移, 遠隔転移を疑う新規病変は認められなかったため, アスピリ ン単剤継続下に左下葉切除 +ND2a-1 を行った。術後経過は良好で, 術後 6 日目に自宅退院となった.

索引用語 : 原発性肺癌, 肺葉切除, 虚血性心疾患, 抗血小板薬 2 剂併用療法 primary lung cancer, lobectomy, ischemic heart disease, dual antiplatelet therapy

\section{はじめに}

近年, 肺癌患者の高齢化に伴い心・血管疾患や脳血管 障害などの合併症を併存し, 術前に抗血小板療法又は抗 凝固療法が施行されている肺癌手術症例が増加してい る. 同様に心血管系疾患の精査の過程で偶発に指摘され る肺癌症例も増加していると考えられる. 虚血性心疾患 に対しては多くに経皮的冠動脈インターベンション (PCI : percutaneous coronary intervention) が行われて おり, 呼吸器外科紹介時には抗血小板剂内服中であるこ とが少なくない. しかし, 抗血小板剂内服中の呼吸器外 科手術に於いて, その内服継続, あるいは中止について, 明確に記載したガイドラインはない.

今回我々は, 労作性狭心症に対する PCIに引き続く 3 力月の抗血小板薬 2 殽併用療法 (DAPT : dual antiplatelet therapy）終了後に, アスピリン単剤投与下に手

宮崎善仁会病院呼吸器外科 原稿受付 2020年 1 月24日 原稿採択 2020 年 4 月 7 日
術を行った肺癌症例を経験したため報告する.

\section{症例}

症 例: 70歳, 男性.

主 訴：なし.

既往歴：12 歳時に結核性胸膜炎, 70 歳時に糖尿病, 70 歳時に狭心症.

喫煙歴：current smoker（40 本/日 $\times 52$ 年).

現病歴：症例は 70 歳男性. 当院紹介 2 週間前に労作性 狭心症にて前医へ入院となり, 冠動脈造影 (CAG : coronary angiography) の結果, 左冠動脈前下行枝（LAD： left anterior descending artery, seg.6）に $90 \%$ 閉塞病変 が認められたため, 第 3 世代薬剤溶出性ステント（Syn$\mathrm{ergy}^{\mathrm{TM}}$ ：ボストンサイエンティフィックジャパン）が留 置された. 直後より DAPT が開始となった. 同入院中に, 左肺腫瘍が指摘されたため, 当科へ紹介となった。

初診時検査所見: 空腹時血糖 $303 \mathrm{mg} / \mathrm{dl}, \mathrm{HbAlc}$ 8.0\%, CEA $1.2 \mathrm{ng} / \mathrm{ml}$, SCC $0.8 \mathrm{ng} / \mathrm{ml}$, SLX $37 \mathrm{U} / \mathrm{ml}$, シ フラ $1.9 \mathrm{ng} / \mathrm{ml}$ であった.

心電図検查：心拍数は 80 回/分, リズムは整, 軸偏位 
なし，完全右脚ブロック．

経胸壁心臓超音波検査：左心室壁肥厚あり, 明らかな 壁運動異常なし, 肺高血圧なし, 軽度の僧帽弁閉鎖不全, 左室駆出率は 70\%.

胸部 X 線所見（Fig. 1）：左下肺野に $42 \mathrm{~mm}$ 大の境界 明瞭な石灰化病変と, その中枢側に $25 \mathrm{~mm}$ 大の結節性病 変を認めた。

胸部 CT 所見 (Fig. 2)：(A) 左下葉に $23 \mathrm{~mm}$ 大の充害

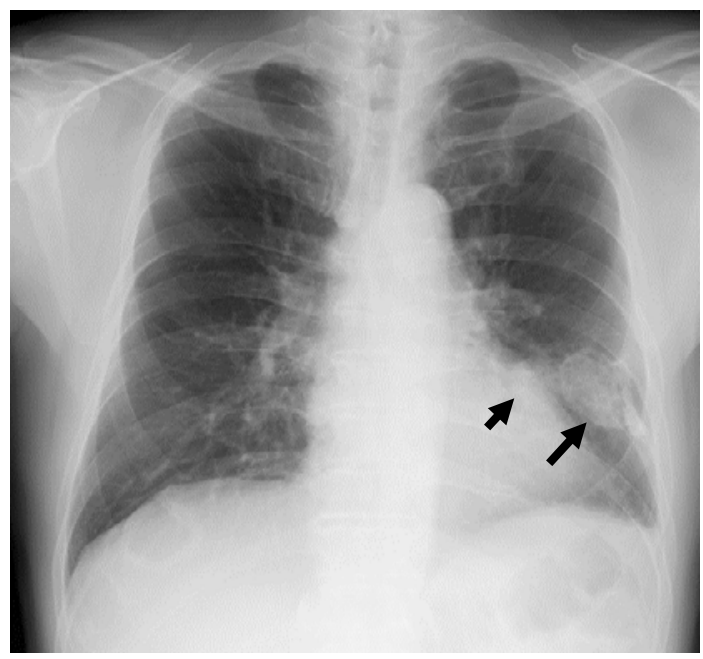

Fig. 1 A chest radiograph shows a clearly demarcated and calcified lesion with a 42-mm mass shadow in the lower left lung field, and a $25-\mathrm{mm}$ nodule shadow centrally.
性腫瘍を認めた。また，その外側胸膜には石灰化病変を 認めた. (B) 縦隔リンパ節の腫大は認められなかった。

PET CT 所見 (Fig. 3)：腫瘍に一致して SUV1 時間值 で 15.8 の異常集積を認めた。リンパ節転移，遠隔転移を 疑わせる所見は認められなかった。

手術に至るまでの経過：当科紹介時, PCI 後のアスピ リンおよびクロピドグレルによるDAPT 中であったた め, クロピドグレルが中止可能となる 3 力月後まで手術 を待機することとした，その間，今回初めて指摘された 糖尿病に治療介入し, 術直前の $\mathrm{HbA1c}$ は $6.8 \%$, 随時空腹 時血糖は 100-150 mg/dl まで改善した. また, 同時に心臓 リハビリテーションを行った. PCI から 3 カ月後, 改めて CAG を行い，LAD ステント留置部の開存も良好である ことが確認された後, アスピリン単剤へと移行した。

術前胸部 CT 所見（Fig. 4）：(A) 左下葉の充実性腫瘍 は $46 \mathrm{~mm}$ 大に増大していた。 (B) 縦隔リンパ節は 3 カ月 前と変化は認められなかった。

経皮的超音波ガイド下腫瘍生検：扁平上皮癌の診断で あった

手術所見：アスピリンは術当日朝も内服した。抗血小 板剤内服継続していたため, 硬膜外麻酔は行わず，術後 フェンタニルの持続静脈注射を計画した. 12 歳時の結核 性胸膜炎の既往と思われる胸膜の広範な石灰化病変を認 めていたため, $10 \mathrm{~cm}$ の後側方開胸および one port assist で手術を行った，術前の予想通り，広範な板状癒着があ
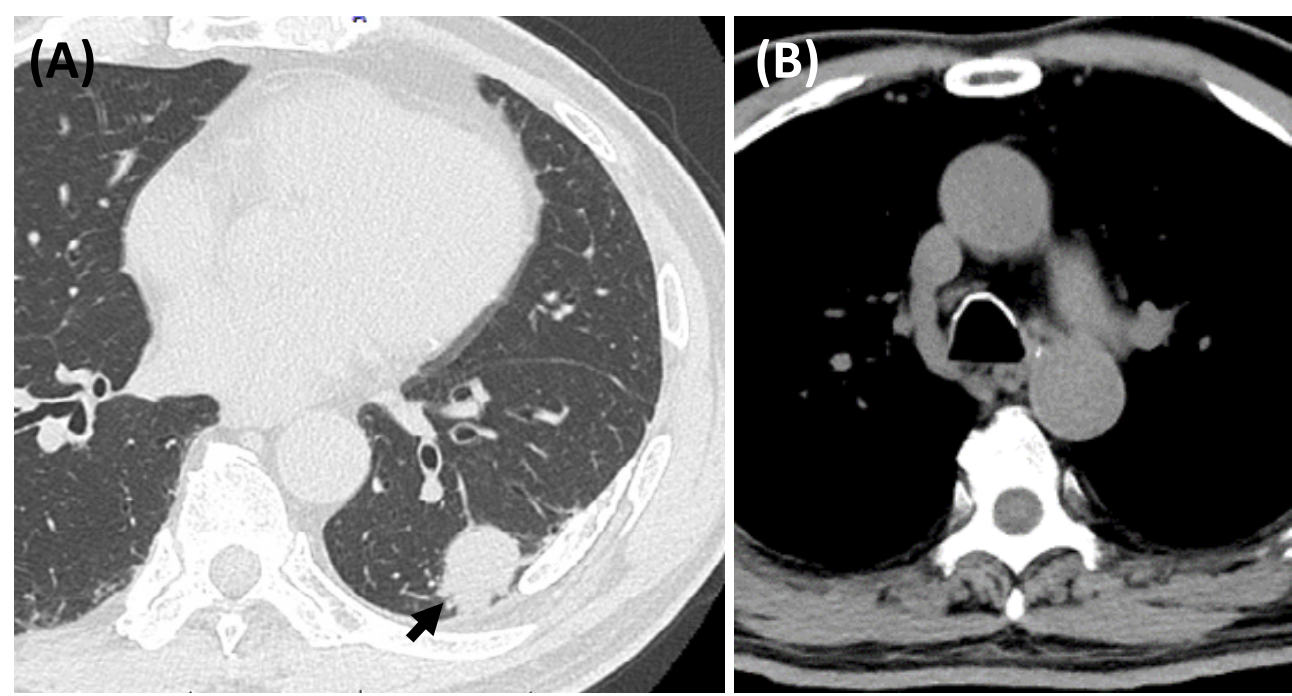

Fig. 2 (A) Chest CT shows a solid tumor of $23 \mathrm{~mm}$ in the left lower lobe. A calcified lesion was found in the outer pleura. (B) No enlargement of the mediastinal lymph nodes was found. 


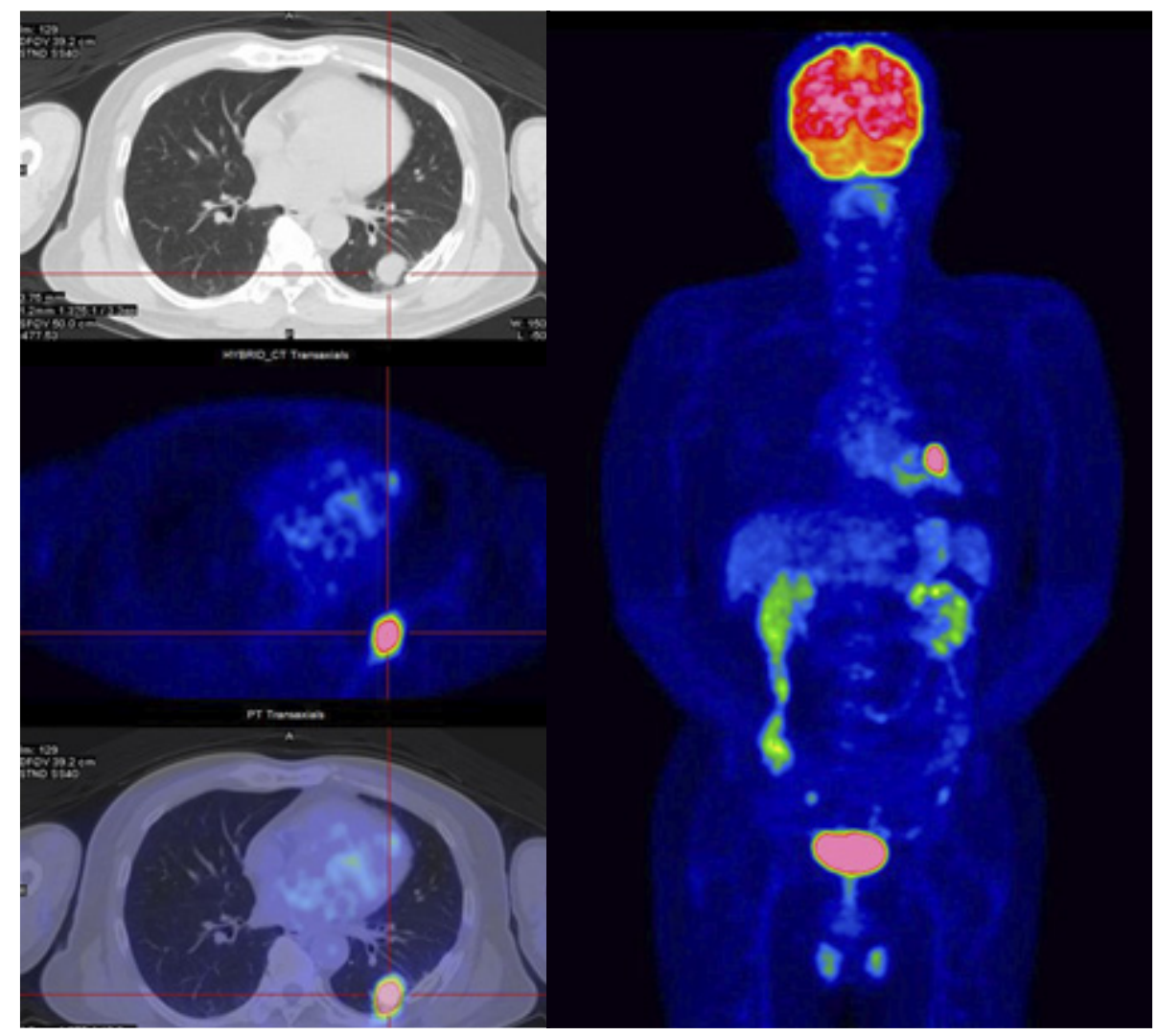

Fig. 3 PET CT shows a mass with FDG accumulation (SUV $\max =15.8$ ) in the left lower lobe, as Fig. 2 indicates. No findings suggestive of lymph node or distant metastasis were found.

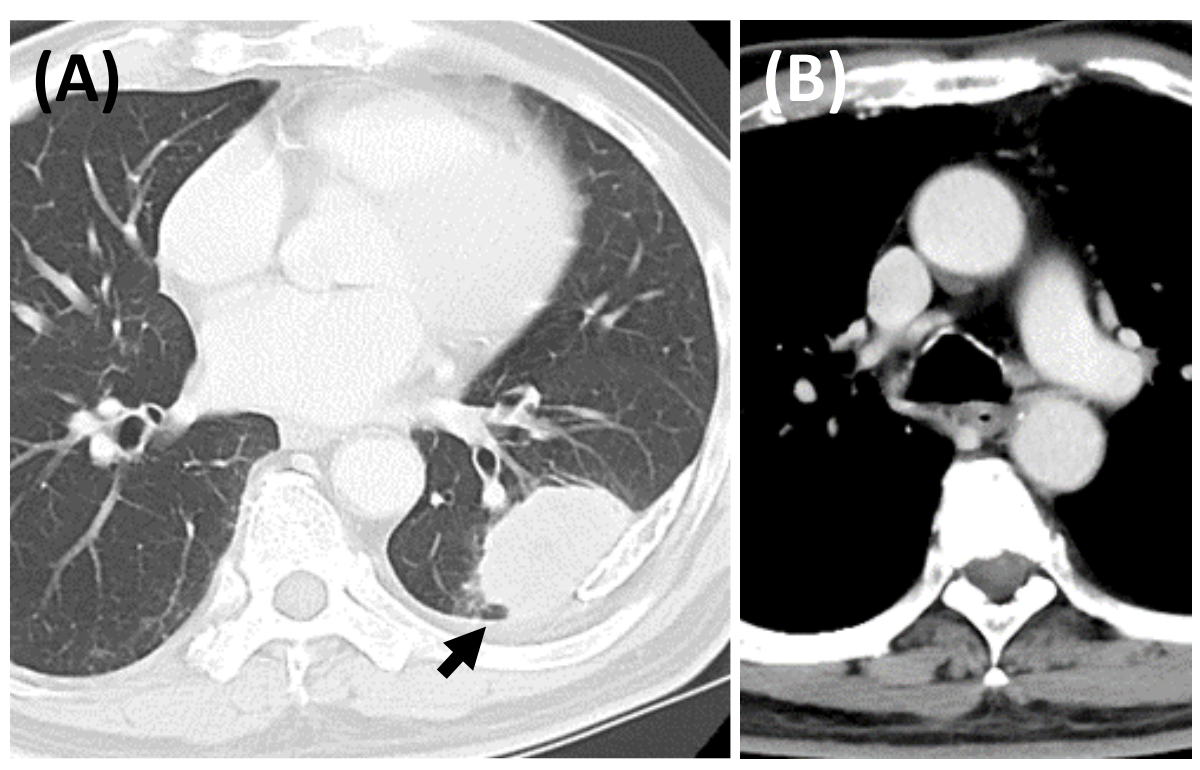

Fig. 4 (A) The solid tumor in the lower left lobe had grown to $46 \mathrm{~mm}$. (B) The mediastinal lymph nodes showed no change at 3 months. 
り, extra-pleural での癒着剥離を行った，当初の計画通 り, 左下葉切除 + ND2a-1 を行った. 術前精査でリンパ節 転移を疑う所見なく, 併存疾患を勘案し, 上縦隔郭清は 省略した，気管支断端の被覆は行わなかった，術中出血 量は $235 \mathrm{ml}$, 手術時間は 5 時間 34 分であった. 輸血は行 わなかった。

術後経過：術翌日朝もアスピリンは内服し，そのまま 退院まで継続した。術後胸腔ドレーンについては術翌日 までに淡血性排液が $384 \mathrm{ml}$, 術後 2 日目までに淡血性排 液が $282 \mathrm{ml}$ 認め, 術後 3 日目に $250 \mathrm{ml}$ で同日抜去した. 術後 6 日目に軽快退院となった。

術 後病理: 腫 瘍 径; $4.5 \mathrm{~cm} \times 3.0 \mathrm{~cm} \times 4.0 \mathrm{~cm}$, Squamous cell carcinoma, G3, ly0 v0, pl0, br(-), pT 2bN0M0, Stage IIA の診断であった.

術後補助化学療法: pStage IIA であり, ガイドライン に従って CDDP + VNR を提案し, 同意を得て開始した が, 消化器副作用にて 1 コースで断念した. 以後は UFT を内服中. 術後 1 年現在無再発生存中である.

\section{考察}

冠動脈疾患の発症リスクについては, 男女ともに哭煙 者で高いことはかねてょり報告されているとおりであ $ろ^{1,2)}$.

一方，喫煙に対する肺癌のリスクについても，喫煙者 は非喫煙者と比較し, 男性では肺癌全体で約 4.5 倍, 女性 では肺癌全体で約 4.2 倍リスクが高まるといわれてい る ${ }^{3)}$.このことから, 虚血性心疾患の精査および治療の過 程で胸部 CT を施行された場合, 偶発に指摘される肺癌 は通常のスクリーニングよりは高くなる可能性が示唆さ れる。

虚血性心疾患に対し, PCI が施行された場合, 留置した ステント部に血栓を生じ冠動脈の閉塞を引き起こすステ ント血栓症が問題となり，それを防止する上で，現在で はアスピリンとクロピドグレルの併用がステント留置後 の標準的な抗血小板薬 2 郕併用療法 (DAPT) とされてい $ろ^{4)}$.

そのため, 虚血性心疾患の精査の過程で肺癌が指摘さ れた場合, PCI のタイミング, およびステントの種類を含 めた治療戦略が重要となる。

ステント表面を新生内膜が被覆するとステント血栓症 は発生しにくくなる.1力月ほどで被覆されるbare metal stent (BMS) と異なり, 薬剤溶出性ステント (drug eluting stent：DES）では薬剤の細胞増殖抑制作用によ り, ステント表面の被覆が遅れるため, DAPT について は, 長期間の抗血小板療法が必要である。これを踏まえ, 内外のガイドラインではDAPT の期間を BMSでは 1 力月, DES では 12 力月程度と提示している.

DPAT 期間内に抗血小板剤を中止し, ヘパリン置換し た上で手術を行うことについては，DESや BMS 留置患 者におけるへパリン投与がステント血栓症を予防すると

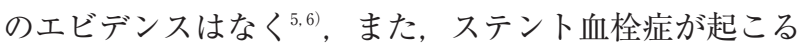
と急性心筋梗塞の発症や死亡など重大な転帰をたどるこ とが多く予後不良な病態であることが知られている.

Tada らは一定期間経過後, 特に第 2 世代の DES ではス テント血栓症発症リスクの経時的増加はみられなくなっ たが, 留置後 1 年はステント血栓に留意すべきと報告し ており ${ }^{7)}$, ヘパリン置換がエビデンスのないものであれ ば, やはりDPAT 期間の抗血小板剤の中止はためらわれ る. 実際, 松岡らは, 周術期にヘパリン置換を施行した 84 例の中で, 術後 3 日目に左冠動脈前下行枝のステント 血栓症を発症した死亡例を報告している8

一方, 最新の第 3 世代 DES ではステント血栓症の頻 度が大きく減少しており, Solo Aspirin After 3 Months of Post-Stent DAPT Safe in High-Bleed-Risk Patients : EVOLVE Short DAPT Study ${ }^{9}$ の結果を受け, DAPT の期間を 3 力月程度に短縮できる可能性が示されてい る。我々の症例においても, 第 3 世代ステント（Syn$\left.\mathrm{ergy}^{\mathrm{TM}}\right)$ が留置されたため, 3 力月で DAPTを終了し, アスピリン単剤継続下に手術を行った。アスピリン単剤 継続下の肺癌肺切除周術期の安全性については Oscars$\operatorname{son}^{10)}$ ら, Yu ら ${ }^{11)}$ の報告をはじめ, 多数の報告がみられ る. $\mathrm{Yu}$ らはその報告の中で患者背景を一致させた対照 群 106 例と比較し, 58 例の検討に於いて術中, 術後出血 は増えなかったことを報告している ${ }^{11)}$.

次に, 第 3 世代 DES による PCI を施行した際の, 3 カ 月間の手術待機については, 薄田らは肺癌の一般的な腫 瘍倍加時間は約 120 日と報告し ${ }^{12)}$, また Aoki らは腺癌で $533 \pm 381$ 日, 扁平上皮癌で $129 \pm 97$ 日, 小細胞癌で 97 \pm 46 日と組織型に応じて腫瘍倍加時間は異なると報告 しており ${ }^{13)}$, up stage のリスクはあるものの, 全く容認で きないものではないと考える。しかし, 我々の症例にお いては, 3 カ月の待機の間に, $23 \mathrm{~mm}$ から $46 \mathrm{~mm}$ への腫 瘍サイズ増大を認め, 結果, up stage した。やはり手術 待機時期に関しては慎重にならざるを得ない. 
一方, 更なる DAPT 期間の短縮についても臨床研究が 行われている. Watanabe ら (STOPDAPT-2) は, 標準 12 力月 $\mathrm{DAPT}$ と 1 力月 $\mathrm{DAPT}$ を比較する非劣性 RCT （Randomized Clinical Trial）を行った $(\mathrm{n}=2,974)$ 結果, 1 カ月 DAPT とそれに続く抗血小板剂単剂（ただし，こ こではクロピドグレル）療法の一次エンドポイント非劣 性・優性が示された。主要二次エンドポイントでも同様 であった ${ }^{14)}$.

様々な要因を勘案し，PCI 施行前に肺癌が認められた 場合は, その時点で循環器内科医と協議し, 留置するス テントをDAPT 期間の短いBMSにし，肺切除を行う か, あるいは一旦経皮的古典的バルーン血管形成術 (percutaneous old balloon angioplasty：POBA）で冠血流を 維持させておいて, 肺切除が終わった後, 速やかに改め て冠動脈造影を行い, DES を留置することを考慮すべき であろう。

問題は, 我々の症例のように PCI で DES が留置され, その後, 肺癌が指摘された場合である。我々は, ガイド ラインを遵守し，DAPT 終了を待った結果，up stage させてしまった，反省点は経過をみながら，増大スピー ドが速いと判断した時点で，DAPT 終了を待たず，抗血 小板剂 2 剂を継続させたまま手術を行うべきであったか もしれない，検索した限り，本邦報告ではクロピドグレ ル内服継続下の胸部外科手術の安全性を報告した文献は 見当たらなかった。しかし, Cerfolio らは, その報告の中 でクロピドグレル内服を中止することなく行った 33 症 例に対する胸部一般外科手術の安全性を報告してい る ${ }^{15)}$. また前述の Yu らの 164 例の抗血小板薬継続下の 胸腔鏡下肺切除については，その抗血小板内服内容はア スピリン単剤，クロピドグレル単剤，アスピリン+クロ ピドグレルであった ${ }^{11)}$. 本邦におけるクロピドグレル内 服継続下の肺切除安全性のまとまった報告が期待され る.

\section{結 語}

今回我々は経皮的冠動脈形成術 $(\mathrm{PCI})$ に引き続く, 抗 血小板薬 2 剂併用療法の後, アスピリン単剂継続下に手 術を行った原発性肺癌の 1 例を経験したため報告した。 PCI 後の肺切除の治療戦略については, 更なる検討が必 要と思われる.
利益相反

本論文について申告する利益相反はない.

\section{文献}

1. Baba S, Iso H, Mannami T, Sasaki S, Okada K, Konishi M, et al. Cigarette smoking and risk of coronary heart disease incidence among middle-aged Japanese men and women: the JPHC Study Cohort I. Eur J Cardiovasc Prev Rehabil 2006; 13: 207-13.

2. Matsunaga M, Yatsuya H, Iso H, Yamashita K, Li Y, Yamagishi K, et al. Similarities and differences between coronary heart disease and stroke in the associations with cardiovascular risk factors: The Japan Collaborative Cohort Study. Atherosclerosis 2017; 261: 124-30.

3. Sobue T, Yamamoto S, Hara M, Sasazuki S, Sasaki S, Tsugane S. Cigarette smoking and subsequent risk of lung cancer by histologic type in middle-aged Japanese men and women: The JPHC study. Int J Cancer 2002; 99: 245-51.

4. 許 俊鋭, 今中和人, 上田裕一, 齋木佳克, 澤 芳樹, 末 田泰二郎, 他. 非心臟手術における合併心疾患の評価と管 理に関するガイドライン（2014 年改訂版）［Internet］東 京：日本循環器学会 [Cited:2019 Aug. 10] Available from: http://www.j-circ.or.jp/guideline/pdf/JCS2014_ky o_h.pdf.

5. Darvish-Kazem S, Gandhi M, Marcucci M, Douketis JD. Perioperative management of antiplatelet therapy in patients with a coronary stent who need noncardiac surgery: a systematic review of clinical practice guidelines. Chest 2013; 144: 1848-56.

6. Brilakis ES, Banerjee S, Berger PB. Perioperative management of patients with coronary stents. J Am Coll Cardiol 2007; 49: 2145-50.

7. Tada T, Byrne RA, Simunovic I, King LA, Cassese S, Joner $\mathrm{M}$, et al. Risk of stent thrombosis among baremetal stents, first-generation drug-eluting stents, and second-generation drug-eluting stents: results from a registry of 18,334 patients. JACC Cardiovasc Interv 2013; 6: 1267-74.

8. 松岡崇志, 井上幸治, 水野 桂, 北 悠希, 仲西昌太郎, 浅井聖史, 他. 周術期の抗血栓療法をへパリンに置換した 
手術症例の検討. 泌尿紀要 2012; 58: 223-6.

9. Mauri L, Kirtane AJ, Windecker S, Yeh RW, Dauerman HL, Price MJ, et al. Rationale and design of the EVOLVE Short DAPT Study to assess 3-month dual antiplatelet therapy in subjects at high risk for bleeding undergoing percutaneous coronary intervention. Am Heart J 2018; 205: 110-7.

10. Oscarsson A, Gupta A, Fredrikson M, Järhult J, Nyström M, Pettersson E, et al. To continue or discontinue aspirin in the perioperative period: a randomized, controlled clinical trial. Br J Anaesth 2010; 104: 305-12.

11. Yu WS, Jung HS, Lee JG, Kim DJ, Chung KY, Lee CY. Safety of thoracoscopic surgery for lung cancer without interruption of anti-platelet agents. J Thorac Dis 2015; 7: 2024-32.

12. 薄田勝男, 斎藤泰紀, 相川広一, 桜田 晃, 陳 炎, 遠
藤千顕, 他. 原発性肺癌における tumor doubling time の臨床病理学的特性. 肺癌 1994; 34: 875-81.

13. Aoki T, Nakata H, Watanabe H, Nakamura K, Kasai T, Hashimoto H, et al. Evolution of peripheral lung adenocarcinomas: CT findings correlated with histology and tumor doubling time. AJR Am J Roentgenol 2000; 174: 763-8.

14. Watanabe H, Domei T, Morimoto T, Natsuaki M, Shiomi H, Toyota T, et al. Effect of 1-Month Dual Antiplatelet Therapy Followed by Clopidogrel vs 12-Month Dual Antiplatelet Therapy on Cardiovascular and Bleeding Events in Patients Receiving PCI. The STOPDAPT-2 Randomized Clinical Trial. JAMA 2019; 321: 2414-27.

15. Cerfolio RJ, Minnich DJ, Bryant AS. General thoracic surgery is safe in patients taking clopidogrel (Plavix). J Thorac Cardiovasc Surg 2010; 140: 970-6.

\title{
A case of primary lung cancer treated without interruption of aspirin monotherapy after dual antiplatelet therapy following myocardial infarction
}

\author{
Akihiro Yonei, Hirokazu Moriyama \\ Department of Respiratory Surgery, Miyazaki Zenjinkai Hospital
}

We report a case of pulmonary resection of lung cancer after percutaneous coronary intervention performed under aspirin monotherapy after dual antiplatelet therapy.

The case was a 70-year-old man. Two weeks prior to referral to our department, he was admitted to a cardiovascular facility for exertional angina, and a drug-eluting stent was placed. Immediately after this, he was started on aspirin and clopidogrel. During hospitalization, a left lung tumor was detected, and so he was referred to our department. Three months after completion of the dual antiplatelet therapy, coronary angiography confirmed good patency of the stent, and the patient was continued on aspirin therapy alone. During the clinical course, the size of the left lower lobe lung tumor increased from 23 to $46 \mathrm{~mm}$, and a diagnosis of squamous cell carcinoma was obtained using ultrasound-guided percutaneous needle biopsy. No new lesions associated with suspected lymph node or distant metastasis were found on contrast-enhanced computed tomography (CT) or positron emission tomography (PET) CT. Left lower lobectomy+ND2 a-1 was then performed under continuous aspirin therapy alone. The postoperative course was good, and he was discharged home 6 days after the operation. 